\title{
Паломничество Шивов 1536 года и конкиста Юкатана: версии эпизода истории поздних майя
}

\begin{abstract}
Аннотахия: статья посвящена одному из ключевых эпизодов истории поздних юка танских майя, истреблению знати одной из наиболее могущественных династий Юкапана - Шив - их старыми противниками из рода Кокомов. Как принято считать историками конкисты, это была главная причина, приведшая их в лагерь испанщев и позволившая конкистадорам после двух неудачных попыток наконеи завоевать полуостров. Источниковедческим аспектам при изучении этого эпизода уделялось мало внимания. Существующие версии содержа $\mathrm{m}$ разные даты происшествия, состав и чели паломничества. Разбор версий, сохранившихся в раннеколониальных письменных источниках, методом простой перекрестной критики показывает, ито все они в действительности восходят к пострадавшей стороне, т. е. Шивам, и в течение короткого времени преврашаются в описания якобы имевших место посольств Шивов к испанщам, сообщения о которых были приняты на веру крупными историками конкисты (Р. Чэмберлен, В. И. Гуляев); эти источники отражают мнение заинтересованной стороны. Недавние источниковедческие исследования О. Харада и Т. Хиллеркюсса показывают, насколько легко их авторы шли на манипуляиию фактами. Документы, созданные индейскими авторами после конкисты, выдержаны в «лоялистском» духе и искажают факты либо умалчивают о неприглядных с точки зрения морали и культуры завоевателей фактах (таких, например, как языческие куль ты). Этими исследователями показано, ито отношение к испанским завоевателям на фоне общей разобщенности политий Юкатана никак не зависело от взаимоотношений местных правителей. Роковой характер эпизода с истреблением паломников в Оимале преувеличен историками. Династия Шив активно искала союза слюбой силой, враждебной Кокомам, и это было одной из скрытых челей «паломничества». Резуль таты исследования приводят к переоиенке некоторых ключевых эпизодов завоевания Юкатана.
\end{abstract}

Ключевые слова: история, конкиста, Юка тан, посольство, майл, постклассика, Шив, Коком, колониальный режим, календарь майя, Оималь, кучкабаль.

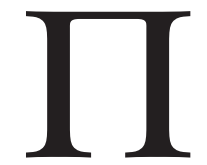

аломничество, совершенное знатью одной из майяских политий Юкатана - Мани - считается событием, окончательно решившим исход конкисты в пользу испанцев. Завоевание Юкатана было одним из самых нелегких предприятий конкистадоров на территории Мексики. Оно проходило в несколько этапов и заняло много времени. Дважды, в 1528 г и в 1533 г, испанцам приходилось оставлять Юкатан. Последнее крупное государство, объединявшее полуостров, Майяпан, распалось в 1441 г. и верховного правителя, захват которого мог бы облегчить им завоевание на Юкатане, не было ${ }^{1}$. Встречавшиеся

\footnotetext{
${ }^{1}$ См., например: Гуляев В. И. Последам конкистадоров. М.,
} 1976. C. 154. на его территории союзники ограничивались выражениями дружбы, но не предоставляли военной помощи, а приведенные из Мексики контингенты союзных науа не сильно облегчали задачу . Местные правители, разобщенные и вечно воевавшие друг с другом, нападали на отряды пришельцев.

Событие, о котором идет речь в статье, представляет собой трагический инцидент , который, как считалось историками конкисты, в корне изменил ситуацию и позволил испанцам заключить союз с правившей Мани династией Шивов 2. Этот знат-

\footnotetext{
${ }^{2}$ Кнорозов Ю.В. «Сообщения о делах в Юкатане» Диего де Ланда как историко-этнографический источник // Ланда, Диего де. Сообщения о делах в Юкатане. М-Л. 1955. С. 26; Гуляев В. И. указ. соч. С. 123, 126.
} 


\section{Регионы мира в мировом историческом процессе}

ный линидж был одним из наиболее могущественных на полуострове: ему подчинялись сразу две политии - куикабали ${ }^{3}$, с центрами в Мани и Калотмуле $^{4}$. Последовательная поддержка им испанцев как в ходе последней (третьей) попытки завоевания полуострова (в 1541-1542 гг.), так и в ходе последовавших в 1546-1547 гг . антииспанских восстаний, позволила им захватить полуостров и удержать его.

Внимание, у деленное этому эпизоду историками-майянистами, нельзя признать достаточным. В основном он привлекал внимание историков конкисты в связи с поиском поворотного момента в ходе испанского завоевания. Майянистов первых поколений паломничество интересовало в связи с приводимыми по майяскому календарю датами, с целью установления корреляции с европейским летоисчислением. Специальное внимание ему было у делено Г. Спинденом и А. Т оззером - единственными специалистами, затронувшими историографические аспекты этого эпизода ${ }^{5}$. Исторический и историографический контекст этого события выводит на ряд смежных и не менее важных вопросов. Так, сам выбор маршрута паломников проливает свет на взаимоотношения политий, о которых из иных источников нам известно мало. В то же время последние источниковедческие исследования в области поздней юкатанской истории позволяют иначе взг лянуть как на само событие, так и на влияние различных его трактовок на видение истории майя ${ }^{6}$. Мы поста-

\footnotetext{
${ }^{3}$ Формы политической организации майя, называемые этим словом определялись специалистами то как «местные государства», то как вождества, то как «города-государства». Но по нашему мнению, речь идет скорее о сложных вождествах. Мы будем использовать для их обозначение слово «полития», которое применяется для характеристики сложных форм социально-политической организации безотносительно к их атрибуции в рамках конкретных моделей политической организации. См.: Гуляев В. И. Города-государства майя. М. 1979, C. 211; Roys R .L. The Political Geography of the Yucatán Maya. Washington, 1957, p. 4-7; Marcus J. Ancient Maya political organization // Lowland Maya Civilization in the Eighth Century A.D. Washington, 1993. P. 156-57.

${ }^{4}$ См.: Quezada S. Pueblos y caziques yucatecos, 1550-1580. México, 1993. Р. 163-164. Во всех более ранних работах два этих кучкабаля не разделяются специалистами, считаясь одной «провинцией Мани». На самом деле несколько наиболее могущественных линиджей (Шив, Купуль, Печ) контролировали, по-видимому, несколько кучкабалей.

${ }^{5}$ Landa's. Relación de las cosas de Yucatán. ed. A.Tozzer. PMP. Vol. XVIII. Cambrige, 1941. P. 54-55, n. 269; Chamberlain R. S. Conquista у colonización de Yucatán. México, 1974; Гуляев В. И. По следам конкистадоров. М. 1976. С. 123, 145.

${ }^{6}$ Наследием Чи специально занимались Ф. Блом, О. Харада и Г. Хиллеркюсс. См.: Blom F. Gaspar Antonio Chi, Interpreter // American Anthropologist, New Series, Vol. 30, No. 2 (Apr. - Jun., 1928), P. 250-262; Harada T. O. Gaspar Antonio Chi Xiu: el, que «perpetuo» la imagen de los Xiu. m.s. 2000. (доклад на 50-м Меж-
}

раемся раскрыть комплекс связанных с этим происшествием проблем.

Обратимся к самому событию. В разных источниках рассказ о паломничестве передается несколькими версиями. В них приводятся разные даты происшествия и различный состав паломников, указываются разные цели и даже меняется трактовка характера мероприятия, в поздних версиях превратившегося из паломничества к языческим святыням в посольство в поддержку бу дущего испанского вторжения. Неизменным остается только место происшествия - Оцмаль, город к юго-востоку от Г. Сотута.

Вот как передает детали этого происшествия епископ Юкатана Диего де Ланда, помещая его между вторым (1531-1533) и третьим (1541) приходами испанцев, ког да страну поразил голод, вызванный отрывом людей от земледельческих работ и беспорядочным расходованием припасов на пищу сражавшимся против испанцев воинам: «Из-за этого голода Шиу , сеньоры Мани, решили устроить торжественное жертвоприношение идолам, приведя некоторых рабов и рабынь, чтобы бросить в колодец Чичен-Ицы. Так как нужно было пройти селение сеньоров Кокомов, их смертельных врагов, они послали просить у них позволения пройти по их земле, полагая, что в такое время те не возобновят старую вражду. Кокомы их обманули хорошим ответом. Они их поместили всех в большом доме и подожгли, убивая тех, кто спасался. Изза этого начались большие войны» ${ }^{7}$. Такая версия приведена в дошедшем до нас сокращенном тексте Ланды. Хронист Антонио Эррера-и-Т ордесильяс, автор сверхпопулярной и неоднократно переиздававшейся в XVII-XIX вв. работы о завоевании Нового Света, пользовавшийся полным текстом работы епископа, уточняет, что в пытавшихся спастись людей стреляли из лука ${ }^{8}$.

Местом паломничества был жертвенный карстовый колодец - сенот (юк. tz'onot) ${ }^{9}$ находившийся среди развалин покинутого в XI в. города Чичен-Ица (столицы государства, согласно традиции,

дународном Конгрессе американистов в Варшаве); Hillerkuss, T. Los meritos y servicios de un maya yucateco principal del siglo XVI y la historia de sus probanzas y mercedes // Estudios de Historia Novohispana. 1993. Vol. 13. P. 9-39.

7 Ланда, Диего де. Сообщения о делах в Юкатане. М-Л. 1955. C. $130-131$.

${ }^{8}$ Herrera-y-Tordesillas A. Historia general de los hechos de los castellanos en las islas y tierra firme del mar oceano. Madrid, 1601. P. 258.

${ }^{9}$ Карстовый колодец, провал, через который подземные воды выходят на поверхность. Единственный вид источников пресной воды на Юкатане. 


\section{Исторический журнал: научные исследования № 4 (16) • 2013}

\section{DOI: $10.7256 / 2222-1972.2013 .4 .9222$}

объединявшего в IX-XI вв. весь Юкатан). Т уда, по свидетельству Ланды, накануне конкисты майя бросали предметы и людей, предназначенных в жертву богам ${ }^{10}$.

Вероломство Кокомов объясняется довольно просто. Вражда двух линиджей уходила корнями ко времени гибели майяпанского госу дарства, которым в это время правили представители рода Кокомов, носившие титул ко-текпан («находящийся во дворце»). В 1441 г. знать, недовольная последним из правителей этой династии, подняла мятеж и истребила всех членов рода Кокомов, за исключением ушедшего в торговую экспедицию младшего сына правителя. Столица, Майяпан, была оставлена, и Кокомам пришлось основывать новые владения, последним центром которых стала Сотута. Главными участниками заговора считались именно Шивы из Мани. Кокомы оказались обложены врагами, и ко времени конкисты эта династия еще не смогла восстановить свою численность: им даже не удалось посадить своих представителей во все подчиненные им территориальные общины - ках ${ }^{11}$.

Расположение места происшествия, Оцмаля, находившегося недалеко от Сотуты, долгое время оставалось неизвестным. Только сравнительно недавно он был обнаружен по указаниям и обследован экспедицией К. Брауна ${ }^{12}$.

Много вопросов вызывает выбор паломниками маршрута. Руины Чичен-Ицы находились либо на территории кучкабалей линиджа Купуль, с которыми кучкабали Шивов Мани и Калотмуль непосредственно не граничили. Кучкабаль Сотута, через который проходил наиболее прямой и короткий путь к руинам Чичен-Ицы, был расположен в центральной части полуострова и его можно было бы обойти. Почему Шивы, подставляясь под у дар, доверились своим старым и непримиримым врагам и не нашли другой путь? Ведь Кокомы, как показывает анализ данных «Сообщений с Юкатана», со времен гибели в 1441 г . майяпанского государства были буквально обложены врагами.

Вероятны две версии. Первая, наименее убедительная, что Кокомы были главой некоей коалиции, и потому проще было просить о проходе именно через их земли. Но сведения о взаимоотноше-

\footnotetext{
10 Ланда, Диего де. Указ. соч. С. 112-114, 153, 155, 202, 204.

11 Ланда, Диего де. Указ. соч. С. 118-124; Queazada S. Op. cit. Р. 167.

${ }^{12}$ Cм.: Brown C., Peraza Lope C., Witschey W., Rogers R., Results of Survey in Central Yucatán, México. Ms. Paper presented at the Symposium "Regional and Community Organization in the Northernm Lowlands: Papers in Honor of the Life and Legacy of Ed Kurjack" celebrated at $76^{\text {th }}$ Annual Meeting of the Society for American Archaeology San Juan, Puerto Rico, April 29th, 2006.
}

ниях независимых «провинций» Юкатана больше говорят о конфликтах, нежели о союзах. Поэтому более вероятна другая версия: независимо от отношений этих областей к Кокомам, Шивам было еще труднее договориться с ними (видимо потому, что у них не было постоянных связей с территориями, непосредственно с ними не граничившими). Эту версию тру дно проверить: о взаимоотношениях политий сохранилось очень мало сведений. Наиболее подробные сведения приводит Д. де Ланда, но то, что он пишет , касается отношений только трех «майяпанских» линиджей: Кокомов, Ч'ель и Шив: «Между тремя домами г лавных сеньоров, какими были Кокомы, Шиу и Чели, происходили раздоры и вражда, которые продолжаются до сегодняшнего дня, хотя они стали христианами. Кокомы говорили о Шиу, что те были иностранцами и предателями, убившими своего законного сеньора и разграбившими его владения. Шиу говорили, что они столь же благородны, столь же древни и такие же сеньоры, как и Кокомы, и что они, убив тирана, были не предателями, а освободителями родины. Чель говорил, что он столь же благороден, как и они, по происхождению, бу дучи внуком наиболее почитаемого жреца Майяпана, и что он лично был лучше их, так как сумел сделаться таким же сеньором, как они. При этом они делали друг другу пищу безвкусной, так как Чель, заняв побережье, не хотел давать ни рыбы, ни соли Кокому, заставляя его ходить очень далеко за ними, а Коком не разрешал доставлять к Челю дичь и фрукты» 13

Прочие сведения о взаимоотношениях политий и правителей позднего Юкатана приходится собирать по крупицам. Воевали с Комами и их соседи на востоке, Купули, контролировавшие несколько кучкабалей ${ }^{14}$. Шивы, в свою очередь, также не отличались миролюбивым нравом. Скорее всего, здесь сыграл роль фактор соседства политий и их положения. Шивы не пошли через земли соседей Кокомов с северо- и юго-запада - Мотуль Печей («провиниия Кех-Печ») и Кочвах линиджа того же имени (со столицей в Тихосуко, Ti-ho-tzuc), что скорее всего указывает на их враждебные отношения. В то же время об отношениях кучкабалей династий Печь и Кочвах с Сотутой ничего неизвестно ${ }^{15}$.

\footnotetext{
13 Ланда, Диего де. Указ. соч. С. 124.

${ }^{14}$ Relaciónes historico-geograficos de la gobernación de Yucatán. México, 1983. T. II P. 216-217.

15 Ройс указывал на то, что Кокомы вошли в провинцию Кочвахов для консультации с ними в 1545 г. во время составления описи документов земель Сотуты, проводимой по приказу испанцев. Но это не обязательно говорит об их дружественных отношениях до конкисты, как полагал этноисторик. См.: Roys R. Op. cit. 1957, P. 137.
} 
Путь паломников мог бы пройти через Хокабу и затем через земли Ч'елей в земли Купулей, где располагались руины Чичен-Ицы. Хокаба, в которой правил линидж Йут, воевала с Сотутой ${ }^{16}$. Но и этот путь отпал по неизвестным причинам: возможно, из-за очевидной нелюбви к Шивам Ч’елей или потому, что конечная цель «паломничества» находилась в земле К упулей, к которым мог ли не питать теплых чувств практически все их соседи (известно, что К упули из Пополы воевали с побережьем и какими-то « селениями Мериды», т . е. на западе полуострова, помимо Сотуты) ${ }^{17}$. Об отношениях кучкабаля Кочвах, через который проходил другой путь из Мани к Купулям, с кем бы то ни было, не известно ничего, но и он отпал. ${ }^{18}$ В итоге Шивы выбрали самый опасный, хотя и самый короткий путь - через Оцмаль.

Прочие версии избиения паломников почти все имеют индейское происхождение, но не всегда отражают «индейский» взгляд на события. В частности потому, что приводятся в текстах прошений и документов, предназначенных для испанской администрации и составленных заинтересованными, то есть лояльными, лицами, либо самими испанцами со слов информированных лиц. Событие отмечено и в записанных латиницей на юкатекском языке текстах книг Чилам-Балам из Мани, Чумайеля и Т исимина и в других документах, г де описываются события времен конкисты. Все эти версии либо симпатизируют династии Шив, пострадавшей в этой истории, либо восходят к ней.

Упоминания об этом эпизоде в стиле, очень похожем на тексты книг Чилам-Балам, есть в документах самого семейства Шивов. В тексте, переписанном 29 мая 1685 г . Хуаном Шив Киме, сказано: «1537 8-го Кавак, первого Поп, умерли «приносящие дождь» (ah pulhaob) в Оцмале, по именам Ax Ц’ун Тутуль Шив и Ах Сийя[н] Напук Чи и Намай Че и Намай Т ун и Ах мен Эван...люди Мани они были, «приносящие дождь» в Чичен-Ице тог да, и спаслись...Нахау У еех, Напот Ковох, 10 Сип это произошло, было 12 Ахав, год 2 Йашкин...». ${ }^{19}$ Этот текст, как и тексты Чилам-Балам, содержит датировки по «короткому счету» календаря майя. По указанной дате «короткого счета» А. Тоззер датиро-

\footnotetext{
16 В «Сообщении из Хокабы» сказано, что она вела войну с соседними провинциями, но не говорится с какими. В 1542 г. они вместе с Шивами и Канулями помогли испанцам подавить восстание Кокомов и Ч'елей. См.: Relaciones...T. I. P. 133, 146, 67.

${ }^{17}$ Relaciones... T. II, P. 216-217.

${ }^{18}$ Исключая испанцев, которых они встретили враждебно, как Купули и Кокомы Relaciones...T. I. P. 29.

${ }^{19}$ Papeles de los Xui de Yaxa, Yucatán. México, 2001. P. 100.
}

вал события августом 1536 г., а не 1537 г. ${ }^{20}$ Первое число месяца Поп (начало года майя) именно на 1536, а не 1537 г. (по европейскому григорианскому летоисчислению) приходится, сог ласно «Кодексу Переса» (т.н. Чилам-Балам из Мани), с начальным знаком 8 Кавак. Проблемы с корреляцией и достоверностью дат имеются и в «книгах» Чилам-Балам, и это событие - не исключение. В самом «Кодексе Переса», в истории Шивов с момента их миграции с прародины и до конкисты, датой происшествия указан 1536 г . по европейскому летоисчислению, но приведена также от личная от документов Шивов дата по календарю майя: «...нехватало 6 лет до завершения к'атуна 13 ахав, находился на востоке счет года, прошел 4 Кан, настал месяц Поп и 18-го Сип в день 9-го Имишь был убит Ах-Пуль...1536, 60 лет после разрушения Майяпана... ». Переводчик текста на испанский язык Э. Солис-и-Алькала после должности «ах пуль» в скобках указывает имя «На Пот Шив», хотя в оригинале его нет Ах На Пот Шив фигурирует в другом документе «Кодекса» под европейской датой 1541 г . - в списке знати Мани, которую переводчик считает списком истребленного посольства ${ }^{21}$. Этого имени нет «генеалогии Шивов», составленной около 1565 г. Остается полагать, что это - «материнское имя» Ах Ц’ун Шива ${ }^{22}$.

Датировки по другим «книгам» также сильно расходятся между собой. Здесь основной проблемой является привязка даты события по системе счета по циклу из 13 двадцатилетий (к'атунов) к европейской хронологии. В «Книге из Чумайеля» есть две даты инцидента в Оцмале. «Третья хроника», один из документов, входящих в состав этой «книги», относит смерть «ах пуля» На Пот Шива к 1-му году к'атуна 11 Ахав, указывая, что по европейскому исчислению это был 1519 г. Это слишком ранняя дата для испанской конкисты и, приводя европейские даты других событий испанского завоевания, автор этого текста ошибается почти на 20-летие ${ }^{23}$. «Первая Хроника» почти повторяет текст «Кодекса Перес» и присваивает событию дату «158». Р. Ройс счел ее ошибкой, но это может быть запись «1508», что соответствует приведенной в «Кодексе...» версии о том, что паломничество следует поместить за 6 лет до конца катана 13 Ахав. Однако само 20-летие он привязывает к европейской дате неверно, так как на следующий к’атун, 11 Ахав, у него следуют события «1513 г .»,

\footnotetext{
${ }^{20}$ Tozzer A. Op. cit. P. 54-55.

${ }^{21}$ Codice Perez. Mérida, 1949. P. 253, 268-269.

${ }^{22}$ Roys R. Op. cit. p. 65.0 проблеме «материнских имен» см:. .

${ }^{23}$ Roys R. L. The Book of Chilam Balam de Chumayel. Washington, 1933. P. 142
} 


\section{Исторический журнал: научные исследования № 4 (16) • 2013}

\section{DOI: $10.7256 / 2222-1972.2013 .4 .9222$}

без указания туна 24 . Это слишком ранняя дата; ошибочность привязок к европейской хронологии видна из многих других мест: неверно датированы приход испанцев, захват Кампече (1513 вместо 1539 г.), приезд и смерть епископов 25 . В текстах книги из Т исимина о паломничестве сказано еще короче: «...13 Ахав случилась смерть приносящего воду»; как и в «Кодексе Переса», событие помещено за шесть лет до конца к’атуна. Переводчик М. Эдмондсон полагает, что имеется в виду 1539 г . Скорее всего, имеет место ошибка в датировках и корреляции с европейской системой летоисчисления, что видно из приводимых в тексте европейских дат: например, смерть епископа Диего де Ланды (1579) здесь отнесена к 1550 г. ${ }^{26}$.

Юкатекские тексты на латинице содержат разные даты, но не упоминают о характере события и об участии в нем Кокомов. Единственной причиной этого являются особенности преподнесения сообщений о гибели правителя в текстах автохтонного происхождения. Как видно по другим текстам («Хроника из Калькини» и др.), описывая смерть своих правителей или правителей противника, не было принято говорить об обстоятельствах происшествия. На его характер (гибель в бою с противником или на его жертвенном алтаре) вседа есть только незначительные косвенные указания (такие как место, где случилась смерть правителя или члена династии: например, поселение на территории соседей ${ }^{27}$.

\footnotetext{
${ }^{24}$ Нумерованного года двадцатилетия.

${ }^{25}$ Roys R. Ibid. P. 81, 138.

${ }^{26}$ Ancient Future of the Itza. The Book of Chilam Balam of Tizimin. Austin, 1982. P. 162.

27 Это можно увидеть, сравнив версии происхождения линиджа Ч'ель у Ланды и в «Историко-географических сообщениях с Юкатана». В хронике Калькини сказано, что несколько членов правящего этой областью линиджа Кануль «умерли» в Мани Шивов, с которым они, по всей видимости, воевали. Сам факт военных действий (рассказ о которых при правлении испанцев не был на пользу их репутации в глазах колониальных властей) также восстанавливается по косвенным указаниям. Так, незадолго до прихода испанцев, «умер» правитель одного из поселений близ границы с Мани, Цемес-Акаля. Канули сменили его правителя-батаба из рода Муут батабом из своего линиджа. Но вместо поселения ранга центра территориальной общины (юк. ках), куда обычно и сажали представители правящего политией линиджа своих членов, оно названо в «Хронике...» «деревней» (юк. какаб). «Деревни» были слишком мелки, чтобы иметь правителя ранга батаба. Поэтому издатель и переводчик текста О. Харада предположил, что Цемес-Акаль был завоеван, а его правитель убит. То, что поселение находилось близ владений Мани, где «умерли» другие представители рода Канулей, по нашему мнению, говорит об экспансии в сторону Мани и войнах Мани и Канулей. В колониальное время оба рода, сотрудничавшие с испанцами в подавлении мятежей, видимо, не спешили вспоминать подробности своих старых взаимоотношений, хотя обычно старые распри переносились линиджами прежних правителей в колониальный период. См.: Codice de Calkini, 1992, P. 80-84, 131-132.
}

Гаспар Антонио Чи, соавтор множества анкет королевского опросника, один из основных информаторов Диего де Ланды, чей взг ляд на историю Юкатана в целом и роли его родственников Шивов был растиражирован различными испанскими источниками, также у делил особое внимание истории гибели паломников. Но в своей пробансе ${ }^{28}$ от 1580 г. он и его свидетели уже говорят о мероприятии Шивов как о посольстве, чьей целью было не принесение жертв языческим богам, а.... склонение Кокомов к союзу с испанцами! Чи заявлял об убийстве Кокомами «40 г лавных персон» из числа знати Мани, в их числе правителя На Пот Шива, названного дядей Гаспара Антонио Чи, и $a x$ к'улеля 29 Чи, отца Гаспара Антонио, в «Кодексе Переса» названного жрецом, ах-к'ином Чи ${ }^{30}$. Причиной нападения уже называются не старые распри линиджей, а то, что Шивы ввели в страну испанцев. Однако решение о союзе с испанцами, сог ласно «книге из Чумайеля», было принято после этого происшествия и именно под впечат лениями от оного: «...1537 г. В день 9 Кавак, собрались альмехены ${ }^{31}$ в городе Мани обсудить, должны ли они привести в свои селения иноземцев, потому что их халач-виник был убит. Вот их имена: Ах Мочан Шив, На Хау Эц, Ах Ц’ун Чинаб, Напоот Купуль, Напоот Че, Набатун Ица, Ах к’ин 32 Эван из Кавкеля... все это важные люди, которые говорили о приведении иноземцев в поселение (cahal) иноземцев, потому что халач-виник поселения, Ах ...Шив был убит в Оцмале» ${ }^{33}$.

Этот текст не свободен от анахронизмов и реверансов в сторону непричастных коллаборационистов. Ах-к'ин Эван из Кавкеля указан в цитированных выше документах Шивов из Йаша как погибший. В списке знати Мани из «Кодекса Перес» его нет (хотя там есть ах-к'ин Чи и На пот Шив). Если под ах-кином Эваном из Кавкеля имеется в виду дон Франсиско Эван, бывший жрец и касик Кавкеля, то этот текст «книги» из Чумайеля

\footnotetext{
28 Проверка записанных просителем или истцом сведений путем опроса «надежных» свидетелей, запись показаний свидетелей. К ней прибегали не только при следствии, но и при освидетельствовании предъявляемых просителем сведений о своих заслугах, дающих ему основание претендовать на занятие места, получение пенсии или энкомьенды.

${ }^{29}$ Ах к'улель (юк.) - доверенный агент и представитель правителя перед общиной и внешним миром. Обычно у правителя было несколько таких лиц.

30 Tozzer A. Op. cit. P. 54-55.

${ }^{31}$ Знатные люди, происходящие от знатных майяпанских родов.

${ }^{32} A x$ к'uн - юк. «жрец». Были советниками правителей и реже, в небольших поселениях также встречаются на должности правителей.

${ }^{33}$ Roys R. Op. cit. P. 53, 146.
} 
составлялся довольно поздно 34 . В таком случае автор знал только то, что Эван был уважаемым испанцами коллаборационистом и потому логично смотрелся в списке людей, призвавших иноземцев. Однако он был правителем независимого селения Кавкель в «анархическом» Чакане и не воходил в состав знати Мани. Не исключено, что близость Кавкеля к воинственным Печ мог ла привести его в ряд надежных союзников Шивов, но вряд ли его правителя пригласили бы к обсуждению их внешнеполитических акций. Т акже загадочно его присутствие в «документах Шивов», где помимо этого момента указана не совсем корректная дата гибели посольства - «1537 г.», на который в текстах «пророчеств» Чумайеля приходится собрание по поводу произошедшего инцидента.

Деятельность, историческое наследие Г аспара Антонио и его мотивы не раз становились предметом специального исследования. По-существу , вся его творческая деятельность, в том числе и та, которая касалась оценки места его родственников Шивов в истории Юкатана, была резуль татом его личных амбиций. О. Харада указывает , что он рано разошелся с династией, поскольку в качестве личного переводчика испанского губернатора сотрудничал с властями в процессах 1562 г . против Шивов ${ }^{35}$. Сочиняя прошения, он должен был привести факты служения своих предков испанскому королю, поэтому неу дивительно, что он приписывает своему отцу ведущую роль в установлении сотрудничества с испанцами. По мере того как «старые конкистадоры» и прочие современники и участники конкисты уходили из жизни, к 1590-м гг. он прекратил упоминать подробности, ограничиваясь констатацией факта содействия отца испанцам ${ }^{36}$. Не оставляет больших сомнений его заинтересованность в искажении событий; сам факт посольства к Монтехо в 1533-1534 г . и участие его отца, неизвестные из других источников, вышядит сомнительными. Трудно представить, чтобы после оцмальского инцидента Шивы решились отряжать посольство к Кокомам с предложением подчиниться чужеземцам, которых ни те, ни другие, возможно, еще в глаза не видели. Но при испанцах выгоднее было считать именно так.

Дополнительную путаницу внесли тексты «Историко-географических сообщений» с Юкатана, созданные при консультациях Чи. Конкистадор Алонсо Росадо, энкомендеро поселений Ц’ан, Па-

\footnotetext{
34 Самая ранняя дата, которой датирован один из документов, -1580 г.

${ }^{35}$ Harada T. Op. cit.

${ }^{36}$ Hillerkuss T., Op. cit. P. 13-14.
}

набчен и Муна, утверждал в своем «Сообщении...», что пострадавший в этой истории На Пот Шив был губернатором Ц’ана, ког да его от дали ему в энкомьенду ${ }^{37}$. А. Тоззер замечал, что энкомьенды раздавались Монтехо в 1542-1545 гг., приходя к выводу, что На Пот Шив должен был быть в это время еще жив (если только речь не идет об «однофамильце»). На том же основании археолог $\Gamma$. Спинден считал, что посольство следует относить к моменту после 1542 г. ${ }^{38}$, что уже невозможно, так как Ланда утверждает, что происшествие случилось между испанскими нашествиями.

В любом случае, приписывать позднюю дату паломничеству Шивов на этом основании не стоит. Ситуация с этой энкомьендой на самом деле более запутанная, чем полагали А. Т оззер и Г. Спинден. Репартимьенто Монтехо было отменено; общины были еще до составления «Сообщений...» перераспределены еще раз после процесса против Монтехо в 1549 г . - и немного странно, что энкомьенду у Росадо не отняли и не дали взамен другую. Допустим, ему повезло. Но есть и другие странные обстоятельства относительно судеб этой энкомьенды, показывающие, что речь шла попросту о подлоге по сговору представителей семейства Шивов с Алонсо Росадо с целью покрыть факт узурпации представителями линиджа Шив положения касиков Ц'ана по праву происхождения. Для этого ими и был «реанимирован» покойный по всем остальным источникам на момент репартимьенто Монтехо На Пот Шив. Разберем ситуацию подробнее, чего не сделали А. Т оззер и Г . Спинден, доверившись сведениям А. Росадо.

Прежде всего, сами упомянутые Росадо касики его селений в других обстоятельствах утверждали, что На Пот Шив все-же погиб в паломничестве. Сын «местного сеньора» На Батун Шива, Хорхе Шив, бывший на момент конкисты, по словам Росадо и «генеалогии Шивов», касиком Панабчена, был свидетелем в упоминавшейся выше пробансе Гаспара Антонио в 1580 г. - т. е. пару лет спустя после составления «Сообщения...», в котором Росадо указывает на На Пот Шива как на живого на момент получения им энкомьенды, Хорхе Шив свидетельствовал, что На Пот Шив, дядя Г аспара Антонио Чи, был убит репартимьенто вместе с его отцом $а x-\kappa '$ ’лем Чи в Оцмале по дороге в Чичен-Ицу в

\footnotetext{
${ }^{37}$ Испанский институт, зародившийся на Пиренейском полуострове. В Испанской Америке подразумевал отдачу поселений с индейцами под покровительство конкистадоров и их потомков на условиях его «опеки». В обмен на нее энкомендеро получал право взимать с населения подать.

${ }^{38}$ См.: Tozzer A. Op. cit., P. 54-55.
} 


\section{Исторический журнал: научные исследования № 4 (16) • 2013}

\section{DOI: $10.7256 / 2222-1972.2013 .4 .9222$}

числе паломников, которым Кокомами были даны

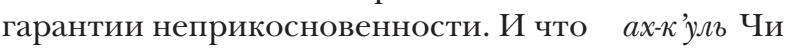
был главным зачинщиком сговора с испанцами (который не мог состояться до гибели паломников, по цитированному выше тексту из Чилам-Балам из Чумайеля). «Сообщения...», напомним, составлялись испанцами при помощи касиков своих селений, то есть, того же дона Хорхе Шив и более того, как указал в своем тексте А. Росадо, при помощи Г аспара Антонио! И этот же самый дон Хорхе Шив, а не кто-то из наследников «На Пот Шива», о котором его энкомендеро, Алонсо Росадо, говорил как о касике Ц'ана на момент получения им энкомьенды, указан в «Сообщении...» касиком селения Ц’ан (и управителем Панабчена). Облегчало ли сговор расположение поселений, неизвестно. Со слов Росадо дело выг лядит так, словно Ц'ан и Панабчен были сведены вместе, так как указаны им как расположенные на равном расстоянии от Мериды, но сам он ничего не говорит насчет их редукиии ${ }^{39}$. Указание, которое проясняет мотивы Шивов и Росадо содержатся в «Земельном договоре из Мани» 1557 г., где губернатором (gov ernador) Ц'ана, что одно и то же что батаби касик, назван Алонсо Пакаб. О. Харада, издатель этого варианта договора, считал, что речь идет об ошибке переписчика ${ }^{40}$.

На самом же деле, на наш взг ляд, речь идет о свидетельстве узурпации линиджем Шив, точнее его представителями из Панабчена, позиции каси$\kappa a$ селения Ц'ан. С этой целью Шивы мог ли между 1557 и 1579 г . объявить «законным сеньором» селения погибшего в паломничестве 1536 г . На Пот Шива. Это объясняет, почему Хорхе Шив, а не потомки Алонсо Пакаба (что по испанскому закону и должно было случиться!) занял должность губернатора Ц'ана. Дон Хорхе высокой нравственностью, кстати, не от личался, как показал Р. Ройс, приведший факты жалоб на злоупотребления им в отношении вверенного ему в попечение имущества 41 . Между тем сын Алонсо Пакаба, упомянутого в «Договоре из Мани», по имени X уан, назван Росадо касиком Муны, а не Ц’ана. Касика Муны на момент

\footnotetext{
${ }^{39}$ A. Tozzer. Op. cit. p. 55; Relaciones... T. I, P. 252-54; Roys R. Political Geography of Yucatan Maya. Whashington. 1957, p. 65. Редукция - сведение нескольких поселений индейцев в более крупные, расположенные поблизости от новооснованных монахами монастырей. При этом, они сохраняли свою идентичность и энкомендеро писали о них как о «селениях», хотя они уже были физически частями, кварталами редукций. На Юкатане процесс сведения в редукции начался в 1552 г. по инициативе ойдора королевской Аудиенсии Гватемала Томаса Лопеса Меделя и францисканского ордена.

${ }^{40}$ Papeles de los Xiu... P. 53.

${ }^{41}$ См.: Roys R. Op. cit. p. 71-72.
}

конкисты Росадо не называет 42 . Видимо, потомков Пакаба по сговору Шивов с А. Росадо «переместили» в Муна, что было операцией незаконной и нормам наследования или получения места касика общины не соответствующей. Т олько испанские энкомендеро могли обменивать энкомьенды, каси$\kappa и$ не мог ли перемещаться из своего поселения в другое. Версия, что Пакаб мог оказаться во г лаве Ц'ана, допустим, по причине гибели На Пот Шива в доколониальный период, отпадает. В этом случае его место должен был бы занять другой представитель Шивов из другой ветви, чему в самом «генеалогическом древе» есть примеры.

Если мы вернемся к вопросу, когда Росадо мог получить энкомьенду, то версия Спиндена о том, что это был 1542, год репартимьенто Монтехо отпадает окончательно. Поселение Муна (Mona) было в 1549 г ., на момент ревизии репартимьенто $\mathrm{Moн}^{-}$ техо, в руках некоего Кастильи, жителя Мериды 43. Когда оно попало в руки Росадо и владел ли он также Ц'аном? Росадо назван в цензе 1549 г . энкомендеро некоего «Хайана», числом 360 плательщиков, который еще $\Phi$. Шоульс предлагал отождествить с Ц'аном только на основании того, что Росадо владел Ц’аном к 1579 г. Но прав ли он? Совсем рядом в цензе упомянут другой «Хайан», 390 плательщиков, от данный Мартину Легисамо. Ройс не хотел считать его тем же поселением, что и «Хайан» Росадо ${ }^{44}$. Скорее всего это так и есть, так как часто поселения от давались двум людям. Например, Сотута Кокомов была поделена между X уаном Маганья (260 плательщиков) и Гонсало Мендесом (360 плательщиков), а уже в 1570-х г. вся Сотута была в руках первого - второго в это время вообее не было среди энкомендеро 45 . О Панабчене в цензе вообще нет ни слова Р . Ройс был уверен, что селения Ц'ан и Панабчен были сведены, хотя не приводит подтверждающих доводов и отождествляет поселения с современными Г. Панабчен и асьендой Ц’ан (в 4,5 км друг от друга).

Таким образом, догадки Т оззера и Спиндена относительно года посольства неверны. На Пот

\footnotetext{
${ }^{42}$ Relaciones... T. I. p. 252.

${ }^{43}$ Tasaciones de los pueblos de la provincial de Yucatán, hechas por la Audiencia de Santiago de Guatemala en el mes de febrero de 1549 // Epistolario de la Nueva España. México, 1939. T. V. P. 148. ${ }^{44}$ Roys, 1957, p. 75; Tasasiones...1939, T. V. p. 155-56.

45 Relaciones... T. I. Р. 36, 150; Tasasiones...T. V. Р. 145. В цензе 1549 г. указано возле каждого из совладельцев, что он владеет половиной селения. Но всегда ли указывалось, что селение в совместном владении? Например, некая «Шучибила» очевидно была разделена между Торресом (230 плательщиков) и Таблада (200 таковых), жителями Кампече, без упоминания об их совместном владении (Tasasiones...1939, T. VI. P.92-93). Их Ройс также пытался проследить как два разных поселения, но безуспешно (Roys R. Op. cit. 1957, p. 118).
} 


\section{Регионы мира в мировом историческом процессе}

Шив в роли касика Ц'ана весьма недостоверно выглядит, как и А. Росадо в числе его первых энкомендеро (тем более, если мы считаем На Пот Шива верховным правителем, халач-виником всего кучкабаля Мани). Возможно, что селение было объявлено принадлежащим На Пот Шиву как верховному «сеньору» провинции, но для администрации это не имело значения и не создавало оснований для перемещения касиков из одного селения в другое. Поэтому и Росадо с Шивами ее пришлось обмануть, предъявив верховного «сеньора провинции» в качестве местного правителя Ц'ана.

Далее мы видим, как усилиями людей, принадлежавших к следующему поколению испанцев, события и причинно-следственная связь в рассказе о языческом паломничестве, постепенно превращающемся в описаниях в благонамеренное посольство, начинает запутываться в клубок. Со слов Чи, автор «Сообщения из Т иаба и Тиек», потомок конкистадора, Хуан Бота, писал: «...После первого вторжения первых конкистадоров, которых сеньоры Мани приняли с миром, без какого-либо сопротивления, выказав подчинение Вашему Величеству, указанный Коком убил предательски более сорока сеньоров указанной провинции Мани, проходивших по его провинции, которые шли с паломничеством безоружные и под гарантиями, отрезав голову и вынув г лаза ах кулелю Чи, который был самым главным (!) среди них, потому что указанные сеньоры из Мани приняли капитанов Вашего Величества с миром и без какого-либо сопротивления и ввели в эту землю люде иноземных и другого закона, указанных испанцев» ${ }^{46}$.

Решение пустить в страну испанцев было принято, по другим данным, после этого эпизода и ахкулель Чи был главным в глазах только одного человека - его сына Гаспара Антонио Чи, в работах которого эта роль возрастает со временем: сведения о своих предках и их деяниях в прошениях о пенсиях и переводах становятся все короче, а их роль в истории Юкатана и его завоевании - все значительнее. Только в пробансах Чи утверждается, что имело место изъявление подданства (как это понимали испанцы) и дружбы (как, скорее всего, виделось индейцам) Шивов из Мани испанцам в ходе вторжения испанцев под началом Франсиско Монтехомладшего в 1531-1534 гг . ${ }^{47}$ На самом деле реакция Шивов на этот приход испанцев из других источников неизвестна. Высадившись на побережье Юкатана, Монтехо-Младший стал созывать в свой лагерь

\footnotetext{
${ }^{46}$ Relaciones...T. I. P. 319.

${ }^{47}$ Hillerkuss T., Op. cit., P. 17.
}

местных правителей, убеждая их прийти и мирно принять испанское подданство. Многие, по словам разных конкистадоров, явились, видимо, чтобы посмотреть на пришельцев. Но неизвестно, были ли среди них Шивы и Кокомы, наиболее активные участники событий следующего испанского вторжения ${ }^{48}$. Впрочем, у Чи был свидетель - «старый конкистадор» Блас Гонсалес, подтвердивший факт первого приема испанцев Шивами, как лично присутствовавший. Сам Г онсалес в своей пробансе не распространяется об этом эпизоде ${ }^{49}$. Вероятно, что он, как Хорхе Шив, просто оказал Чи небольшую услугу, помогая ему получить пенсию. А поскольку в ходе второго завоевания представители правителей подносили дары, о которых в колониальное время коллаборационисты из числа индейской знати предпочитали вспоминать как о первой дани, то неудивительно, что приход посольства был приписан к этому эпизоду конкисты, а не другому.

Еще более позднюю версию приводит хронист Диего Лопес де Когольюдо, автор тру да «История Юкатана» (середина XVII в.). Он также указывает на Оцмаль как место действия, но уже говорит не о паломниках в Чичен-Ицу, а о посольстве Шивов к Кокомам с целью убедить их принять власть испанцев. Само мероприятие он отнес к 1541 г., а приводимый им список почти полностью (кроме происхождения одного из участников) идентичен списку знати Мани из «Кодекса Переса». То, что Когольюдо не был знаком с работой Ланды, видно из того, что он сомневается в дате «1536 г.», поставленной на имевшемся в его распоряжении рисунке с изображениями погибших (в оригинале не сохранившемся) и в том, что погибший На Пот Шив - сам халач-виник Мани, считая его сыном Тутуль Шива. Когольюдо считал, что в бумагах Шивов имеется путаница и речь идет о другом событии, где среди жертв мог быть и халачвиник ${ }^{50}$. Р. Ройс, А. Тоззер, С. Морли и Г. Спинден отмечали, что рисунок с погибшими, который хронист воспроизвел в своем сочинении, очень похож на изображение 13 к'атунов в «книгах Чилам Балам» ${ }^{51}$. Более того: в версии пророчеств Чилана

\footnotetext{
${ }^{48}$ См., например, работу Чамберлена. При этом сам он считает, что Шивы вступали в контакт с испанцами в период этого вторжения, но ссылается при этом только на пробансу Чи. См.: Chamberlain, Op. cit., P. 140-143.

${ }^{49}$ Hillerkuss T., Op. cit., P. 16; Chamberlain R. Probanza de Méritos y Servicios of Blas González, Conquistador of Yucatán // The Hispanic American Historical Review. Vol. 28. No. 4. November 1948. P. 526-536.

${ }^{50}$ Codice Perez...P. 177; Lopez Cogolludo D. Historia de Yucatán. Campeche. 1955. T. I. P. 258-261.

${ }^{51}$ Tozzer A. Op. cit. P. 54-55.
} 


\section{Исторический журнал: научные исследования № 4 (16) • 2013}

\section{DOI: $10.7256 / 2222-1972.2013 .4 .9222$}

Балам в «Кодексе Переса» видно, что вместо изображения покровителей к'атунов воспроизведены головы погибших, взятые именно с этого рисунка и подписанные их именами. Во всяком случае, это те самые погибшие члены линиджа Шив ${ }^{52}$. Так, голова кулеля Чи, которому выкололи глаза стрелой, показана со стрелой, попавшей в глаз и подписана его именем под пророчеством о к'атуне 13 ахав, как и на рисунке Шивов ${ }^{53}$. Сам рисунок, по словам Когольюдо, воспроизведшего его в своей работе, был найден им среди документов представителей рода Шив. Здесь действительно есть основание разделять сомнения Когольюдо. Однако выводы следует сделать прямо противоположные тем, к которым пришел францисканский хронист . А именно, что Шивы тайком сохраняли память о паломничестве, но, желая, чтобы происшествие имело в г лазах католиков-испанцев более благовидный облик, предпочитали скрывать истинную цель путешествия своей знати. Поэтому все попытки отнести его ко времени самих вторжений не имеют смысла.

Как видим, резню в Оцмале приписывали трем разным эпизодам: паломничеству к колодцу (Ланда и книги Чилам-Балам); первому посольству к Монтехо (Г аспар Антонио и его «свидетели»), якобы имевшему место в 1533 г . или в 1534 г ; посольству к Кокомам, будто бы отправленному после того, как Шивы в 1541 г. открыто предложили испанцам союз (Л. Когольюдо, Кодекс Переса). Имеются основания поверить версиям Ланды и Чилам-Балам из Чумайеля, а не поздним пробансам 1580-1590-х гг . Гаспара Антонио, жонг лированию «мертвыми душами» и измышлениям Шивов относительно истории своего сотрудничества с завоевателями. В 1562 г . Диего де Ланда организовал аутодафе над идолопоклонниками и отступниками. В их числе были многие бывшие правители из знатных династий, тайно отправлявшие языческие ритуалы и совершавшие человеческие жертвоприношения. Представителей индейской знати (приравненных испанцами к идальго и носивших титул дон) бросали в тюрьмы, надевали сан-бенито, отдавали в наказание в услужение другим, даже неграм-рабам. Возмущенные и до смерти перепуганные аутодафе, Шивы, хотя и не преминули пожаловаться на Диего де Ланда королю, но навсегда усвоили, что от любой причастности к языческим обычаям, как в современности, так и в прошлом, при испанских властях лучше всячески открещиваться ${ }^{54}$.

\footnotetext{
${ }^{52}$ Codice Perez...P. 133-177.

${ }^{53}$ Codice Perez...P. 172.

${ }^{54}$ Cartas de Indias. Madrid. 1877. T. II. P. 407.
}

Версии произошедшего инцидента настолько расходятся между собой, что на их общее происхождение указывает только место происшествия. Но история появления сведений о «посольствах» Шивов как к испанцам, так и к Кокомам довольно прозрачна. Очевидно, что сведения о первом и втором посольствах к испанцам являются результатом преднамеренного искажения событий языческого паломничества 1536 г . к священному месту для жертвоприношений авторами, симпатизировавшими испанцам и пострадавшим Шивам, либо искавшими собственной выгоды. Ни то, ни другое посольства, по всей видимости, не имели места, хотя автор классической работы о завоевании Юкатана Р. Чамберлен стал жертвой такой фальсификации событий в работах Г . А. Чи. Историк считал, что имели место как паломничество Шивов в ЧиченИцу, так и посольство к Монтехо в 1533-1534 г ., в котором пострадал предок $\Gamma$ аспара Антонио, ссылаясь на прошение последнего. Чамберлен полагал, что гибель посольства была резуль татом антииспанских происков Кокомов. Руку Кокомов он видит почти в каждом акте сопротивления испанцам, даже если речь идет об областях, г де они не имели влияния, как, например, в событиях завоевания Чакана ${ }^{55}$. На самом деле у историка нет подтверждений тому, чтобы Кокомы приняли участие в сопротивлении и вообще вступали в контакт с испанцами ранее событий 1541 г ., ког да те появились непосредственно на территории Сотуты. Влияние, приписываемое Кокомам Чамберленом, явно ретроспективно и основано на их более поздней роли в организации восстания 1546-1547 гг . против испанцев, потому его точка зрения необоснованна (особенно, если учесть сложные отношения между политиями Юкатана, не позволявшие Кокомам инспирировать акции за пределами своих земель) ${ }^{56}$.

Анализ источников приводит нас к следующим выводам. После аутодафе 1562 г . события доиспанской истории стали преподноситься местной знатью более осторожно. Шивы и Г аспар Антонио стали активно открещиваться от причастности к языческим обрядам, приписывая их введение

\footnotetext{
55 Поселения области никогда не объединялись в политиюкучкабаль и несмотря на это, сопротивление здесь было особенно упорным и ожесточенным. Дипломатическое влияние на некоторые поселения Чакана (chacan, на юкатекском «саванна») имели только Печ. Как полагал Р. Ройс, именно эти доколониальные связи скрывались за фактами совместного совершения ими тайных жертвоприношений на границе своих областей уже после испанского завоевания. Cм. Roys R. Op. cit. P. 56

${ }^{56}$ Chamberlain R. Op. cit. P. 60, 133, 141, 209-211, 215.
} 


\section{Регионы мира в мировом историческом процессе}

DOI: $10.7256 / 2222-1972.2013 .4 .9222$

«мексиканскому капитану» Кецалькоат лю или переистолковывая их в более «безобидном» ключе ${ }^{57}$. Эпизод с паломничеством к священному сеноту был выдан за посольство к Кокомам, которых якобы пытались убедить принять испанское подданство. В такой трактовке их поступок должен был выглядеть еще более отвратительным в г лазах испанских покровителей Шивов - тем более, что На Чи Коком (впрочем, как и очень многие главы правящих династий Юкатана) оказался вероотступником, тайно совершавшем жертвоприношения. Позже, желая выставить Шивов и своего предка в качестве людей, первыми принесших дань испанцам, Г. А. Чи стал искажать хронологию событий и утверждать, что $a x-\kappa$ ' $у л ь$ Чи совершил визит к испанцам до 1536 г., т. е. до того, как погиб в Оцмале. Наконец, Когольюдо присваивает событию дату 1541 г. - года начала третьего вторжения испанцев на полуостров (возможно, зная как автор не дошедшей до нас работы о конкистадорах Юкатана, что ранее Шивы не могли иметь дело с испанцами).

Оценка эпизода, тем не менее, должна быть более сдержанной. Как Р. Чамберлен, так и Ю. В. Кнорозов и В. И. Гуляев считали, что это событие было ключевым, роковой случайностью, приведшей к созданию союза Шивов и испанцев, что стало

\footnotetext{
57 Так, обряд жертвоприношения школомче, путем расстрела жертвы из лука, преподносится Г. А. Чи как казнь преступников. А обычай украшать статуи богов, покрывая их накидками из ткани, как средство сохранить их до прихода испанцев. Так как пророк Балам из Мани якобы заранее предсказывал, что этими предметами будущие господа полуострова будут взимать дань. См., например: Chi G. A. Relación sobre los costumbres de los indios // Landa's. Relación de las cosas de Yucatán. ed. A. Tozzer. PMP. Vol. XVIII. Cambridge, 1941. Appendix C. P. 230-33; Relaciones...T. I. P. 69; Torquemada J. Veinte y un libro y monarquía indiana. México. 1969, t. III. P. 132; Lopez de Cogolludo D. Op. cit. 1954. T. I. P. 213.
}

причиной разгрома Кокомов в битве при Мериде (1542) и позволило им захватить полуостров. Но влияние бойни в Оцмале на направление политики Шив, в том числе в отношении испанцев, на самом деле незначительно. Взаимная неприязнь или ее отсутствие не сказывались и на отношении правителей Юкатана к пришедшим испанцам, равно как ничего не менял их приход на взаимоотношения местных правителей. Не любившие Кокомов Шивы и Купули по-разному приняли испанских завоевателей: Шивы - как союзников, Купули - как врагов, в то время как воевавшие друг с другом Ч'ели и Печ одинаково хорошо отнеслись к конкистадорам. Навряд ли Шивы были бы менее расположены помогать испанцам, если бы этот эпизод не случился. Паломничество действительно, скорее всего, имело тайной целью посольство, но не к Кокомам. Святыня, к которой они направлялись, располагалась на территории кучкабаля линиджа К упуль, воевавшего с Кокомами. По нашему мнению, направляясь туда, правитель и знать Шивов могли рассчитывать на проведение переговоров (тем более, что в составе паломников находился и правитель Мани, а это могло привести к координации действий династий Купуль и Шив). В әтом случае они сами дали лишний повод для истребления своего паломничества: такой опасной возможности Кокомы, некогда правители полуострова, существовавшие теперь во враждебном окружении, не мог ли допустить. Шивы искали союзников против Кокомов до того, как испанцы появились на их территории. Вражда обоих родов была старой, не было никаких шансов на их примирение. Даже если бы трагедии в Оцмале не случилось, союз Шивов с испанцами против Кокомов все равно состоялся бы.

\section{Библиография:}

1. Гуляев В. И. Города-государства майя. М. 1979.

2. Гуляев В. И. Последам конкистадоров. М. 1976.

3. Кнорозов Ю.В. «Сообщения о делах в Юкатане» Диего де Ланда как историко-этнографический источник // Ланда, Диего де. Сообщения о делах в Юкатане. М-Л. 1955.

4. Ланда, Диего де. Сообщения о делах в Юкатане. М-Л. 1955.

5. Ancient Future of the Itza. The Book of Chilam Balam of Tizimin. Austin, 1982.

6. Blom F. Gaspar Antonio Chi, Interpreter // American Anthropologist, New Series, Vol. 30, No. 2 (Apr. — Jun., 1928). P. 250-262.

7. Brown C., Peraza Lope C., Witschey W., Rogers R., Results of Survey in Central Yucatán, México. Ms. Paper presented at the Symposium "Regional and Community Organization in the Northernm Lowlands: Papers in Honor of the Life and Legacy of Ed Kurjack" celebrated at 76th Annual Meeting of the Society for American Archaeology San Juan, Puerto Rico, April 29th, 2006.

8. Cartas de Indias. Madrid, 1877. T. II.

9. Chamberlain R. S. Conquista y colonización de Yucatán. México, 1974.

10. Chi G. A. Relación sobre los costumbres de los indios // Landa's. Relación de las cosas de Yucatán. ed. A. Tozzer. PMP. Vol. XVIII. Cambridge, 1941. Appendix C. P. 230-33. 


\section{Исторический журнал: научные исследования № 4 (16) • 2013}

DOI: $10.7256 / 2222-1972.2013 .4 .9222$

11. Cronica de Calkini // Harada O. T. Los Canules: análisis etnohistorico del Codice de Calkini. México. 1992.

12. Codice Perez. Mérida, 1949.

13. Harada O. T. Los Canules: análisis etnohistorico del Codice de Calkini. México. 1992.

14. Harada T. O. Gaspar Antonio Chi Xiu: el, que «perpetuo» la imagen de los Xiu. m.s. (Paper, presented on the 50-th International Congress of Americanists, Warsaw, 2000).

15. Herrera-y-Tordesillas A. Historia general de los hechos de los castellanos en las islas y tierra firme del mar oceano. Madrid, 1601.

16. Hillerkuss, T. Los meritos y servicios de un maya yucateco principal del siglo XVI y la historia de sus probanzas y mercedes // Estudios de Historia Novohispana. 1993. Vol. 13. P. 9-39.

17. Landa's. Relación de las cosas de Yucatán. ed. A.Tozzer. PMP. Vol. XVIII. Cambrige, 1941.

18. Lopez Cogolludo D. Historia de Yucatán. Campeche, 1955. T. I.

19. Lopez Cogolludo D. Historia de Yucatán. Madrid, 1688.

20. Marcus J. Ancient Maya political organization // Lowland Maya Civilization in the Eighth Century A.D. Washington, 1993. P. 156-57.

21. Papeles de los Xui de Yaxa, Yucatán. México, 2001.

22. Quezada S. Pueblos y caciques yucatecos, 1550-1580. México, 1993.

23. Relaciónes historico-geograficos de la gobernación de Yucatán. México, 1983. T. I-II.

24. Roys R .L. The Political Geography of the Yucatán Maya. Washington, 1957.

25. Roys R. L. The Book of Chilam Balam de Chumayel. Washington, 1933.

26. Tasaciones de los pueblos de la provincial de Yucatán, hechas por la Audiencia de Santiago de Guatemala en el mes de febrero de 1549 // Epistolario de la Nueva España. México, 1939. T. V.

27. Torquemada J. Veinte y un libro y monarquía indiana. México. 1969. T. III.

\section{References:}

1. Gulyaev V. I. Goroda-gosudarstva mayya. M. 1979.

2. Gulyaev V. I. Posledam konkistadorov. M. 1976.

3. Knorozov Yu.V. «Soobscheniya o delah v Yukatane» Diego de Landa kak istoriko-etnograficheskiy istochnik // Landa, Diego de. Soobscheniya o delah v Yukatane. M-L. 1955.

4. Landa, Diego de. Soobscheniya o delah v Yukatane. M-L. 1955.

5. Ancient Future of the Itza. The Book of Chilam Balam of Tizimin. Austin, 1982.

6. Blom F. Gaspar Antonio Chi, Interpreter // American Anthropologist, New Series, Vol. 30, No. 2 (Apr.-Jun., 1928). P. $250-262$.

7. Brown C., Peraza Lope C., Witschey W., Rogers R., Results of Survey in Central Yucatán, México. Ms. Paper presented at the Symposium "Regional and Community Organization in the Northernm Lowlands: Papers in Honor of the Life and Legacy of Ed Kurjack" celebrated at 76th Annual Meeting of the 7. Society for American Archaeology San Juan, Puerto Rico, April 29 th, 2006.

8. Cartas de Indias. Madrid, 1877. T. II.

9. Chamberlain R. S. Conquista y colonización de Yucatán. México, 1974.

10. Chi G. A. Relación sobre los costumbres de los indios // Landa's. Relación de las cosas de Yucatán. ed. A. Tozzer. PMP. Vol. XVIII. Cambridge, 1941. Appendix C. P. 230-33.

11. Cronica de Calkini // Harada O. T. Los Canules: análisis etnohistorico del Codice de Calkini. México. 1992.

12. Codice Perez. Mérida, 1949.

13. Harada O. T. Los Canules: análisis etnohistorico del Codice de Calkini. México. 1992.

14. Harada T. O. Gaspar Antonio Chi Xiu: el, que «perpetuo» la imagen de los Xiu. m.s. (Paper, presented on the 50-th International Congress of Americanists, Warsaw, 2000).

15. Herrera-y-Tordesillas A. Historia general de los hechos de los castellanos en las islas y tierra firme del mar oceano. Madrid, 1601.

16. Hillerkuss, T. Los meritos y servicios de un maya yucateco principal del siglo XVI y la historia de sus probanzas y mercedes // Estudios de Historia Novohispana. 1993. Vol. 13. P. 9-39.

17. Landa's. Relación de las cosas de Yucatán. ed. A.Tozzer. PMP. Vol. XVIII. Cambrige, 1941.

18. Lopez Cogolludo D. Historia de Yucatán. Campeche, 1955. T. I.

19. Lopez Cogolludo D. Historia de Yucatán. Madrid, 1688.

20. Marcus J. Ancient Maya political organization // Lowland Maya Civilization in the Eighth Century A.D. Washington, 1993. P. 156-57.

21. Papeles de los Xui de Yaxa, Yucatán. México, 2001. 


\section{Регионы мира в мировом историческом процессе}

DOI: $10.7256 / 2222-1972.2013 .4 .9222$

22. Quezada S. Pueblos y caciques yucatecos, 1550-1580. México, 1993.

23. Relaciónes historico-geograficos de la gobernación de Yucatán. México, 1983. T. I-II.

24. Roys R.L. The Political Geography of the Yucatán Maya. Washington, 1957.

25. Roys R. L. The Book of Chilam Balam de Chumayel. Washington, 1933.

26. Tasaciones de los pueblos de la provincial de Yucatán, hechas por la Audiencia de Santiago de Guatemala en el mes de febrero de 1549 // Epistolario de la Nueva España. México, 1939. T. V.

27. Torquemada J. Veinte y un libro y monarquía indiana. México. 